Crop Breeding and Applied Biotechnology 12: 111-117, 2012

Brazilian Society of Plant Breeding. Printed in Brazil

\title{
ARTICLE
}

\section{Adaptability and stability of maize varieties using mixed model methodology}

Flávia Ferreira Mendes ${ }^{1 *}$, Lauro José Moreira Guimarães ${ }^{2}$, João Cândido Souza ${ }^{1}$, Paulo Evaristo Oliveira Guimarães ${ }^{2}$, Cleso Antônio Patto Pacheco², Jane Rodrigues de Assis $\mathrm{Machado}^{2}$, Walter Fernandes Meirelles ${ }^{2}$, Adelmo Resende da Silva ${ }^{2}$ and Sidney Netto Parentoni ${ }^{2}$

Received 3 November 2011

Accepted 13 March 2012

\begin{abstract}
The objective of this study was to evaluate the performance, adaptability and stability of corn cultivars simultaneously in unbalanced experiments, using the method of harmonic means of the relative performance of genetic values. The grain yield of 45 cultivars, including hybrids and varieties, was evaluated in 49 environments in two growing seasons. In the 2007/2008 growing season, 36 cultivars were evaluated and in 2008/2009 25 cultivars, of which 16 were used in both seasons. Statistical analyses were performed based on mixed models, considering genotypes as random and replications within environments as fixed factors. The experimental precision in the combined analyses was high (accuracy estimates $>92 \%$ ). Despite the existence of genotype $x$ environment interaction, hybrids and varieties with high adaptability and stability were identified. Results showed that the method of harmonic means of the relative performance of genetic values is a suitable method for maize breeding programs.
\end{abstract}

Keywords: BLUP, mixed models, Zea mays.

\section{INTRODUCTION}

In Brazil, maize is grown in a wide variety of environments, at very different levels of technology and investment. The identification of genotypes with a high yield potential, coupled with wide adaptability and stability, is a key target of the maize breeding programs.

A major drawback in the selection of genotypes with high yield capacity in different environments is the genotype $\mathrm{x}$ environment $(\mathrm{GxE})$ interaction. A strong interaction can hamper the selection, since genotypes that perform well in a one environment may not do as well in another. Consequently, the plant performance must be assessed at different locations to reduce the chance of misleading selection results or recommendations. Therefore, aside from the high yield, new cultivars must have yield stability and adaptability, or particular suitability for the target regions. Studies of adaptability and stability parameters greatly contributed in this respect, by providing information about the behavior of each genotype under different environmental conditions.
Several methods of adaptability and stability analysis have been proposed in the literature (Cruz et al. 2004), of which those of simplest interpretation are preferred. Thus, measures that incorporate adaptability and stability as well as yield in a single statistic have been used, e.g., the methods of Lin and Binns (1988) and of Annicchiarico (1992) (Cruz et al. 2004). However, these procedures assume that the genotype effects are fixed, and according to Resende (2007a), this is somewhat limiting for the analysis of unbalanced experiments that have non-orthogonal experimental designs and heterogeneity of variance. On the other hand, the mixed models, in which treatments effects are assumed as random, the genetic effects can be predicted free of the influence of the fixed model effects by using the Best Linear Unbiased Predictor - BLUP (Henderson 1975). The BLUP method has been widely used in data analyses of animal breeding programs, but has only recently been adopted in plant breeding programs (Piepho et al. 2008, Souza Jr 2011).

For the use of mixed models, Resende (2007a) proposed the simultaneous analysis of stability, adaptability

\footnotetext{
${ }^{1}$ Universidade Federal de Lavras, Departamento de Biologia, C. P. 37, 37.200-000, Lavras, MG, Brazil. *E-mail: flvmendes2001@yahoo.com.br

2 Embrapa Milho e Sorgo, MG 424, km 45, 35.701-970, Sete Lagoas, MG, Brazil
} 
and yield based on the harmonic mean of the relative performance of the genotypic values (MHPRVG, in Portuguese). Considering the selection for yield and stability, Resende (2007a) describes the MHVG method (harmonic mean of genetic values), based on estimates of the harmonic mean of the genotypic values for each genotype tested in different environments. The lower the standard deviation of genotypic performance across environments, the greater is the harmonic mean of its genotypic values. Consequently, the selection for higher values of the harmonic mean results in selection for both yield and stability. For adaptability, a simple and effective measure is the relative performance of genetic values (PRVG) across environments. In this case, the predicted genotypic values are expressed as a proportion of the overall mean of each environment and then the average value of this ratio is calculated for each genotype (Resende 2007a).

The MHPRVG combines the methods PRVG and MHVG, simultaneously, penalizing genotype instability, similarly to the measure Pi described by Lin and Binns (1988). Concomitantly, adaptability is capitalized in the sense of responsiveness to environmental improvement, by considering the proportions of means of each genotype in each environment, compared to the overall mean, similar to the method proposed by Annicchiarico (1992).

Aside from the above advantages of MHPRVG, the method can be used with unbalanced data, non-orthogonal designs and heterogeneity of variances. Such situations are mere routine in maize breeding programs, where large numbers of treatments are evaluated at numerous locations (Mi et al. 2011, Souza Jr 2011, Fritsche-Neto 2010). Moreover, the MHPRVG multiplied by the overall mean of the experi- ments provides a measurement in the same magnitude of the parameter evaluated, facilitating agronomic interpretations.

In order to evaluate the adaptability and stability of common bean lines in the state of São Paulo, Carbonell et al. (2007) used the MHPRVG, Lin and Binns (1988) and Annicchiarico (1992) methods. These authors found that almost the same genotypes were selected by the three methodologies. However, the MHPRVG method had the advantage of providing results on the proper scale of the evaluated trait, which can be directly interpreted as simultaneous breeding values for yield, stability and adaptability. Similar results were obtained for rubber tree, sugar cane and eucalyptus (Verardi et al. 2009, Bastos et al. 2007, Pinto Jr. et al. 2006, ).

Given the above, the objective of this study was to evaluate the performance, adaptability and yield stability of 40 maize varieties, two double-cross hybrids and three intervarietal hybrids, using the MHPRVG method.

\section{MATERIALS AND METHODS}

The maize varieties were tested in the growing seasons 2007/2008 and 2008/2009, in trials coordinated by Embrapa Maize and Sorghum, covering 49 environments of the main Brazilian regions (Table 1). The evaluated plant material consisted of 40 open-pollinated varieties, three intervarietal hybrids and two double-cross hybrids, totaling 45 treatments (Table 2). Thirty-six treatments were evaluated in the 2007/2008 growing season and 25 in the following season, with 16 common treatments in both.

The experiment in the $2007 / 2008$ growing season was arranged in a 6x6 simple lattice and in 2008/2009 in a 5x5 simple lattice design. The plots consisted of two 4-m long rows, spaced $80 \mathrm{~cm}$ between rows and $20 \mathrm{~cm}$ between plants.

Table 1. Environments where the maize varieties were assessed in the growing seasons of 2007/2008 and 2008/2009

\begin{tabular}{lll}
\hline State & Environments (growing season 2007/2008) & Environments (growing season 2008/2009) \\
\hline PA & Belterra; Moju; Paragominas & Belterra; Paragominas; Uruará \\
\hline MS & Campo Grande; Dourados; Maracajú & Campo Grande; Dourados; Ponta Porá \\
\hline GO & Goiânia; Planaltina & Goiânia; Planaltina \\
\hline MG & $\begin{array}{l}\text { Guarda Mor; Inhauma; Sete Lagoas alta adubação; Sete Lagoas baixa } \\
\text { adubação; Sete Lagoas orgânico1; Sete Lagoas orgânico 2 }\end{array}$ & $\begin{array}{l}\text { Coimbra alto N; Coimbra baixo N; Janaúba; Lavras; Sete Lagoas alta } \\
\text { adubação; Sete Lagoas baixa adubação }\end{array}$ \\
\hline PR & Londrina CNPSO; Londrina IAPAR & Londrina CNPSO \\
\hline SP & Manduri/Growing season; Manduri/Safrinha; & Manduri/Growing season; Manduri/Safrinha \\
\hline MA & Paraibano & Chapadinha; Mata Roma; São Raim. Mangabeiras \\
\hline MT & Cáceres; Cáceres safrinha; Sinop; Sinop safrinha; Tangará da Serra; & \\
\hline RO & Vilhena & Vilhena \\
\hline AM & Iranduba Terra Firme; Iranduba Várzea & \\
\hline RJ & Campos dos Goytacazes & \\
\hline
\end{tabular}


FF Mendes et al.

Table 2. Treatments to test maize varieties in 2007/2008 and 2008/2009

Genotypes (growing season 2007/2008)

AL 30/40; AL Piratininga; AL Ipiranga; AL Alvorada; AL Bandeirante; BRS Sol da manhã; BRS Eldorado; MC 20; MC 60; UFV 8; UFV 7; UFV 6; SHS 3031; SHS 500EX; BRS Planalto; Missões; SCC 154-Fortuna; CEPAF 2; Fundacep34; Fundacep 35; Fundacep 49; PC 0402; IPR 114; CPATC 4; BR 5011-Sertanejo; VSL FB 33; Sintético 256 L; BR 106; Sintético 1 X; BRS Caimbé; BR 473; Sintético RxSSpod; Sintético SP1; BRS 4103; BRS 2020; BIO 2

Genotypes (growing season 2008/2009)

AEO 2008; AL 30/40; AL BDE/40; AL Piratininga; BR 106; BR 106 Q; BR 473; BRS 4103; BRS Caimbé; BRS Eldorado; BRS Sol da manhã; MC 20; Sint. Pro.V.A; Sint. Multipla TL; Sintético 1 X; Sintético 256 L; Sintético RxSSpod; UFV 7; UFV 8; VSL BS 42 C 60; VSL FB 33; H25ALTA; BIO 4; BRS 2020; BRS 2022

The crop management was performed as recommended for each region and technology level. Grain yield (GY) was evaluated in $\mathrm{kg} \mathrm{ha}^{-1}$ and adjusted to $13 \%$ moisture.

Statistical analyses were performed considering stability and adaptability based on MHPRVG, using model 52 of software SELEGEN-REML/BLUP, proposed by Resende (2007b), assuming that $y=X r+Z g+W b+T i+e$, where $y$ is the vector of observations of the trait; $r$ is the vector of the effects of replications at location (assumed as fixed effect) plus the overall mean. The vector $r$ includes all replications of all locations (fits replication-location combinations). In this case, this vector considers the effects of locations and replications within locations; $g$ is the vector of genotypic effects (random); $b$ is the vector of block effects (random); $i$ is the vector of the GxE interaction (random); and e is the vector of error or residue (random). X, Z, W and T represent the matrices of incidence for the effects of $r, g, b$ and i, respectively. The means and variances were structured and distributed as follows:

$$
\begin{aligned}
& y / r, \quad V \sim N(X r, \quad V) \\
& g / \sigma_{g}^{2} \sim N\left(0, \quad I \quad \sigma_{g}^{2}\right) \\
& b / \sigma_{b}^{2} \sim N\left(0, \quad I \quad \sigma_{b}^{2}\right) \\
& i / \sigma_{i}^{2} \sim N\left(0, \quad I \quad \sigma_{i}^{2}\right) \\
& e / \sigma_{e}^{2} \sim N\left(0, \quad I \quad \sigma_{e}^{2}\right)
\end{aligned}
$$

The mixed model equations provided the genetic values:

$$
\left(\begin{array}{cccc}
X^{\prime} X & X^{\prime} Z & X^{\prime} W & X^{\prime} T \\
Z^{\prime} X & Z^{\prime} Z+I \frac{\sigma_{e}^{2}}{\sigma_{g}^{2}} & Z^{\prime} W & Z^{\prime} T \\
W^{\prime} X & W^{\prime} Z & W^{\prime} W+I \frac{\sigma_{s}^{2}}{\sigma_{b}^{2}} & W^{\prime} T \\
T^{\prime} X & T^{\prime} Z & T^{\prime} W & T^{\prime} T+I \frac{\sigma_{\varepsilon}^{2}}{\sigma_{g a}^{2}}
\end{array}\right)\left(\begin{array}{l}
\hat{r} \\
\hat{g} \\
\hat{b} \\
\hat{i}
\end{array}\right)=\left(\begin{array}{c}
X^{\prime} y \\
Z^{\prime} y \\
W^{\prime} y \\
T^{\prime} y
\end{array}\right)
$$

From the predicted genotypic values $(\hat{g})$, the relative percentages of the genotypic values (PRVG) were estimated for each cultivar in the different environments, by the expression: $P R V G_{i j}=V G_{i j} / V G_{j}$, where $V G_{i j}$ is the genotypic value of cultivar $i$ in environment $j$ and $V G_{j}$ corresponds to the genotypic mean in environment $j$. Subsequently, the harmonic means of the relative performance of the genotypic values for each cultivar were estimated by:

$$
\operatorname{MHPRVG}_{i .}=n / \sum_{j=1}^{k} \frac{1}{P R V G_{i j}},
$$

where $n$ is the number of environments. To facilitate result interpretation, the MHPRVG values were multiplied by the general mean of all environments (GM), providing results in the same magnitude as of the characteristic studied.

Subsequently, separate analyses were conducted for the favorable and unfavorable macroenvironments, resulting in the establishment of MHPRVG values for each case. Thus, to evaluate the adaptability, also considering the cultivar stability, the results of the MHPRVG*GM measures were compared in scatter plots, contrasting favorable and unfavorable macroenvironments. The results of the favorable macroenvironments were plotted on the abscissa and of the unfavorable macroenvironments on the ordinate axis. Thus, the Cartesian plane was divided into four quadrants, where the lower left quadrant represented the cultivars with poorer performance in both groups of environments, indicating a lack of adaptability to any of these macroenvironments and low yield stability, while in the upper right quadrant cultivars with superior performance in both groups of environments can be identified, indicating adaptability to these environments and high stability. The upper left quadrant grouped genotypes with specific adaptability to unfavorable environments while the lower right quadrant contained cultivars with specific adaptability to grow in favorable environments.

\section{RESULTS AND DISCUSSION}

Significant differences between cultivars were observed at $1 \%$ probability by the likelihood ratio test (LRT), in the analysis of deviance considering all environments (Table 3 ). It was therefore inferred that there is variability among cultivars for grain yield. Experimental data are traditionally subjected to analysis of variance, in which the total sum of squares is partitioned in sums of squares of the other model effects. The hypotheses of significance are mostly tested by the ratio between the mean squares of the effects and the error mean square. However, Resende (2007a) emphasized that the contrasts for unbalanced experiments have no variance in common, unlike in the case of balanced experiments. In this case, considering the data analysis in the context of mixed models, the likelihood ratio test proves to be more accurate than the F-test 
Adaptability and stability of maize varieties using mixed model methodology

Table 3. Deviance analysis and estimates of the variance components for grain yield $\left(\mathrm{kg} \mathrm{ha}^{-1}\right)$ of maize cultivars, in the growing seasons $2007 / 2008$ and 2008/2009

\begin{tabular}{|c|c|c|}
\hline Effect & Grain yield $\left(\mathrm{kg} \mathrm{ha}^{-1}\right)$ Deviance & Grain yield $\left(\mathrm{kg} \mathrm{ha}^{-1}\right)$ LRT + \\
\hline Cultivars & 43980.6 & $321.1 * *$ \\
\hline Blocks & 43728.4 & $69.0 * *$ \\
\hline Complete model & 43659.5 & \\
\hline Heritability $\left(h^{2}\right)$ & 0.94 & \\
\hline Genetic correlation between environments & 0.45 & \\
\hline Residual coefficient of variation (CVe \%) & 13.6 & \\
\hline Overall experimental mean $\left(\mathrm{kg} \mathrm{ha}^{-1}\right)$ & 5213 & \\
\hline
\end{tabular}

** Significance at $1 \%$ probability for the likelihood ratio test (LRT); $+x^{2}$ tab $(1 \mathrm{df}): 6.63$ at $1 \%$ probability.

of the analysis of variance. In this context, Piepho et al. (2008) showed that the predictive accuracy of BLUP is better than of other procedures.

Table 3 presents the estimates of the components of genetic and phenotypic variances for grain yield, considering all environments. The heritability for this trait was high (0.94). It can be inferred that the experimental precision in the combined analyses was high, as indicated by the estimate of experimental variation $(\mathrm{CVe}=13.6 \%)$. The estimate of accuracy, which measures the correlation between predicted and true values, was also high (97\%). According to Resende (2007a), the experimental precision can be considered excellent in experiments with accuracy values above $90 \%$.

The overall mean grain yield, considering all environments, was $5213 \mathrm{~kg} \mathrm{ha}^{-1}$ (Table 3$)$. The average grain yield was highest for BRS 2022 (double-cross hybrid), H25 HIGH (intervarietal hybrid), BRS 2020 (double-cross hybrid), BIO 4 (intervarietal hybrid) and $\mathrm{BIO} 2$ (intervarietal hybrid), with estimates above $5877 \mathrm{~kg} \mathrm{ha}^{-1}$. The most productive varieties were BRS Caimbé, ALBDE/40, Al Piratininga and Sint. Múltipla TL, with means over $5500 \mathrm{~kg} \mathrm{ha}^{-1}$, which did not differ from the hybrids BRS 2020, BIO 2 and BIO 4 by the confidence interval (Figure 1).

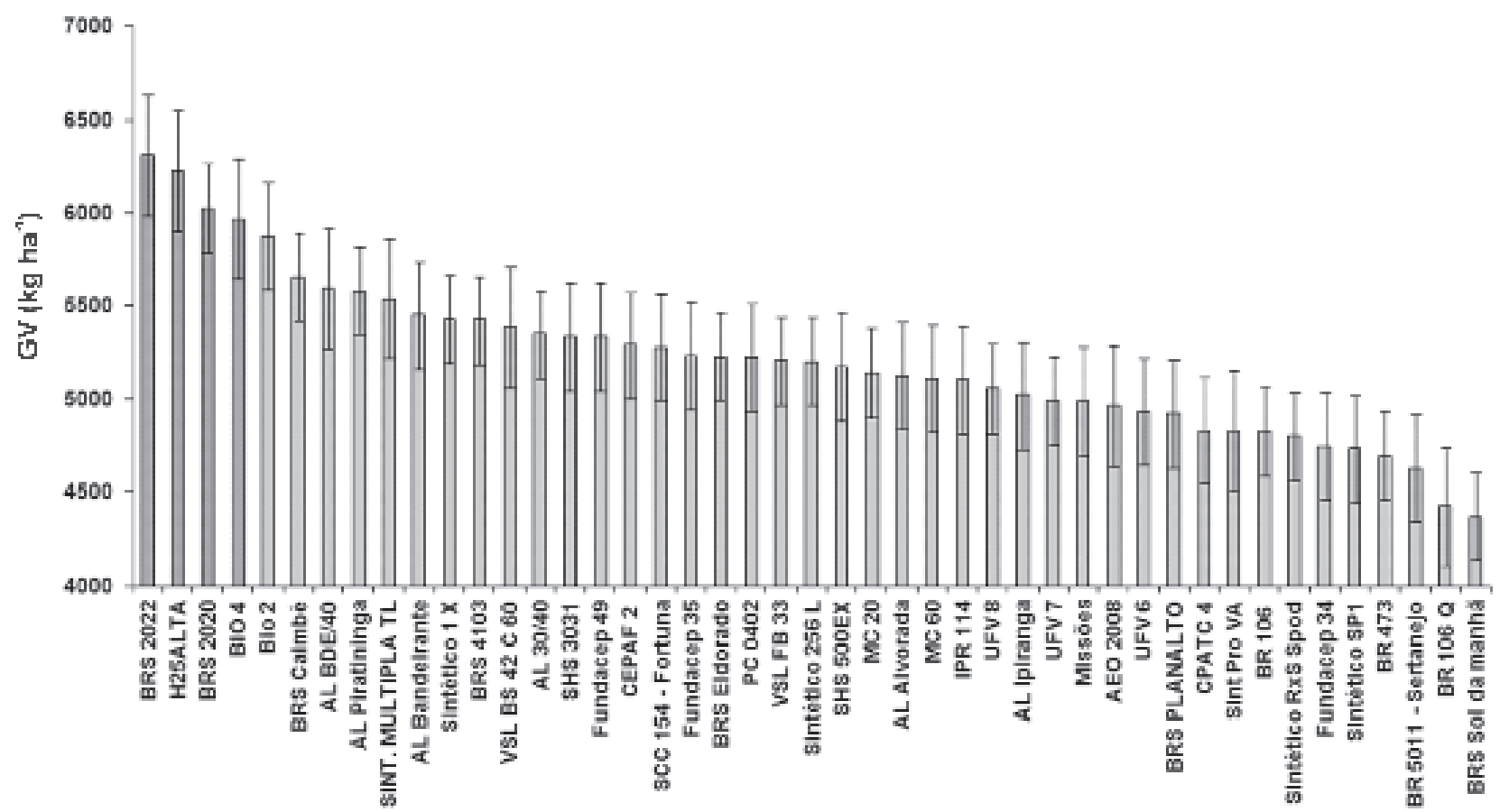

Figure 1. Means of genotypic values (GV) for grain yield of 49 maize cultivars and their respective confidence intervals (bars). 
FF Mendes et al.

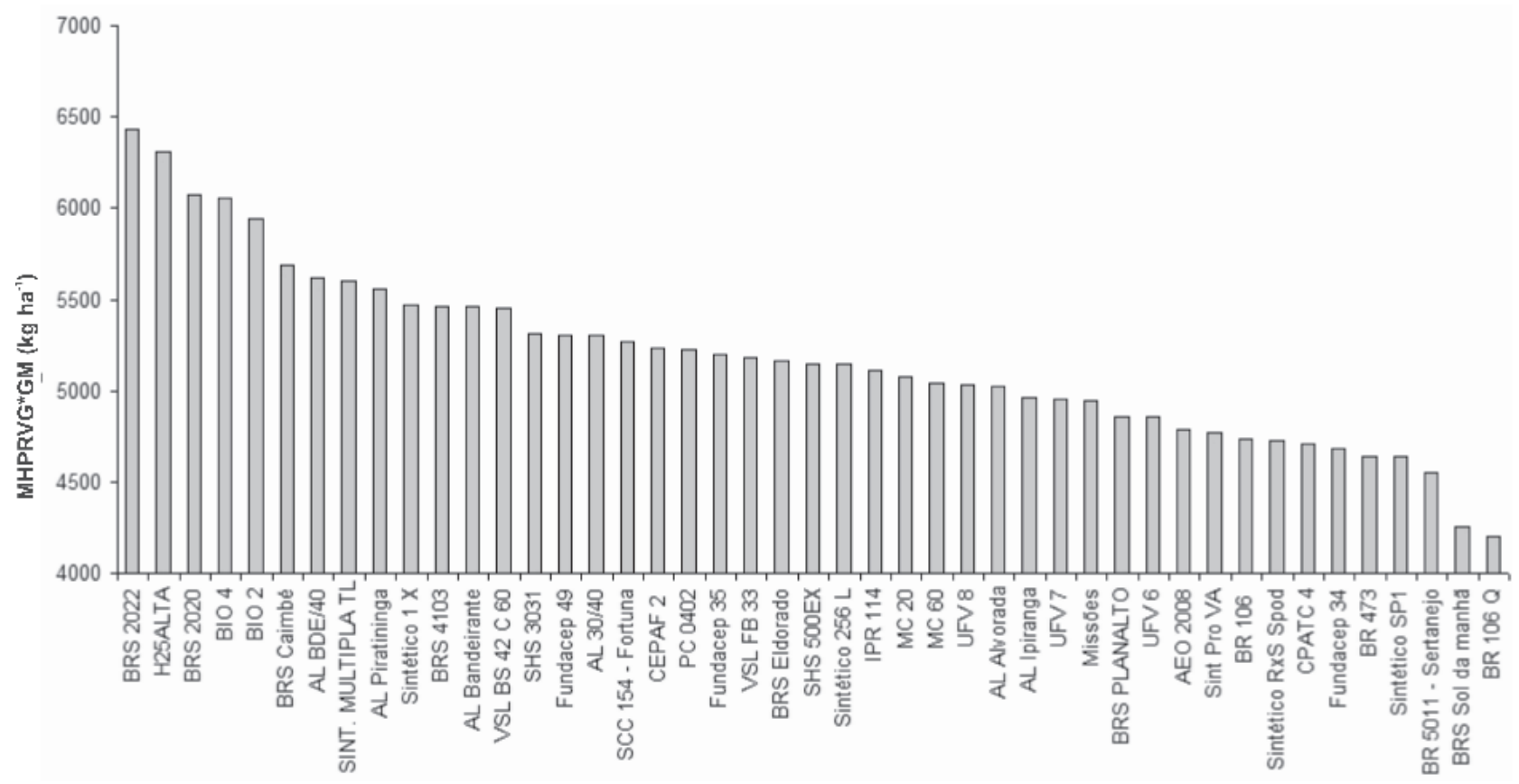

Figure 2. Means of MHPRVG*GM for the 49 maize cultivars.

The hybrids yielded more than the open-pollinated varieties, however, it is worth noting that to obtain seed from hybrid cultivars usually requires detasseling of the female lines in the pollination field, making the seeds more expensive than of open-pollinated varieties. For planting in environments with a high technology level, the best option is the use of hybrids. On the other hand, when corn is grown under less favorable conditions, open-pollinated varieties are more suitable.

It was found that the source of variation for the GxE interaction was significant (Table 3 ). The variance of the GxE interaction for grain yield accounted for $24 \%$ of the phenotypic variance therefore, genotypes with excellent performance in a given environment could not perform as well in other environments.

Figure 2 shows the results of the adaptability and stability measures MHPRVG*GM. Despite the strong GxE interaction, varieties with good adaptability and yield stability were observed. The variety BRS Caimbé performed best, with MHPRVG*GM value of $5688 \mathrm{~kg} \mathrm{ha}^{-1}$, followed by AL BDE/40 and Sint. Múltipla TL. The highest values of MHPRVG* GM were observed for the double-cross hybrid BRS 2022, BRS 2020 and the intervarietal hybrids H 25ALTA, BIO 2 and BIO 4.

The MHPRVG method was also applied separately to the two environment classes. For this purpose, the 49 environments were divided into two groups, based on the average yield at each location. Environments with an average yield above the overall mean $\left(5213 \mathrm{~kg} \mathrm{ha}^{-1}\right)$ were considered favorable and those with averages below this value unfavorable.

The estimate of heritability for grain yield was higher for favorable than for the unfavorable group of environments (Table 4). This same trend was observed for the estimate of accuracy. It was therefore concluded that favorable conditions provided higher experimental precision. On average, the yield was $6383 \mathrm{~kg} \mathrm{ha}^{-1}$ in the favorable and $3779 \mathrm{~kg} \mathrm{ha}^{-1}$

Table 4. Estimates of the variance components for maize grain yield in favorable and unfavorable environments. Growing seasons $2007 / 2008$ and 2008/2009

\begin{tabular}{lcr}
\hline Variance components & Favorable environment & Unfavorable environment \\
\hline Heritability $\left(\mathrm{h}^{2}\right)$ & 0.93 & 0.75 \\
\hline Accuracy & 0.96 & 0.86 \\
\hline Genetic correlation among environments & 0.60 & 0.25 \\
\hline Residual coefficient of variation $(\mathrm{CVe} \%)$ & 12.1 & 16.6 \\
\hline Overall experimental mean $\left(\mathrm{kg} \mathrm{ha}^{-1}\right)$ & 6383 & 3779 \\
\hline
\end{tabular}




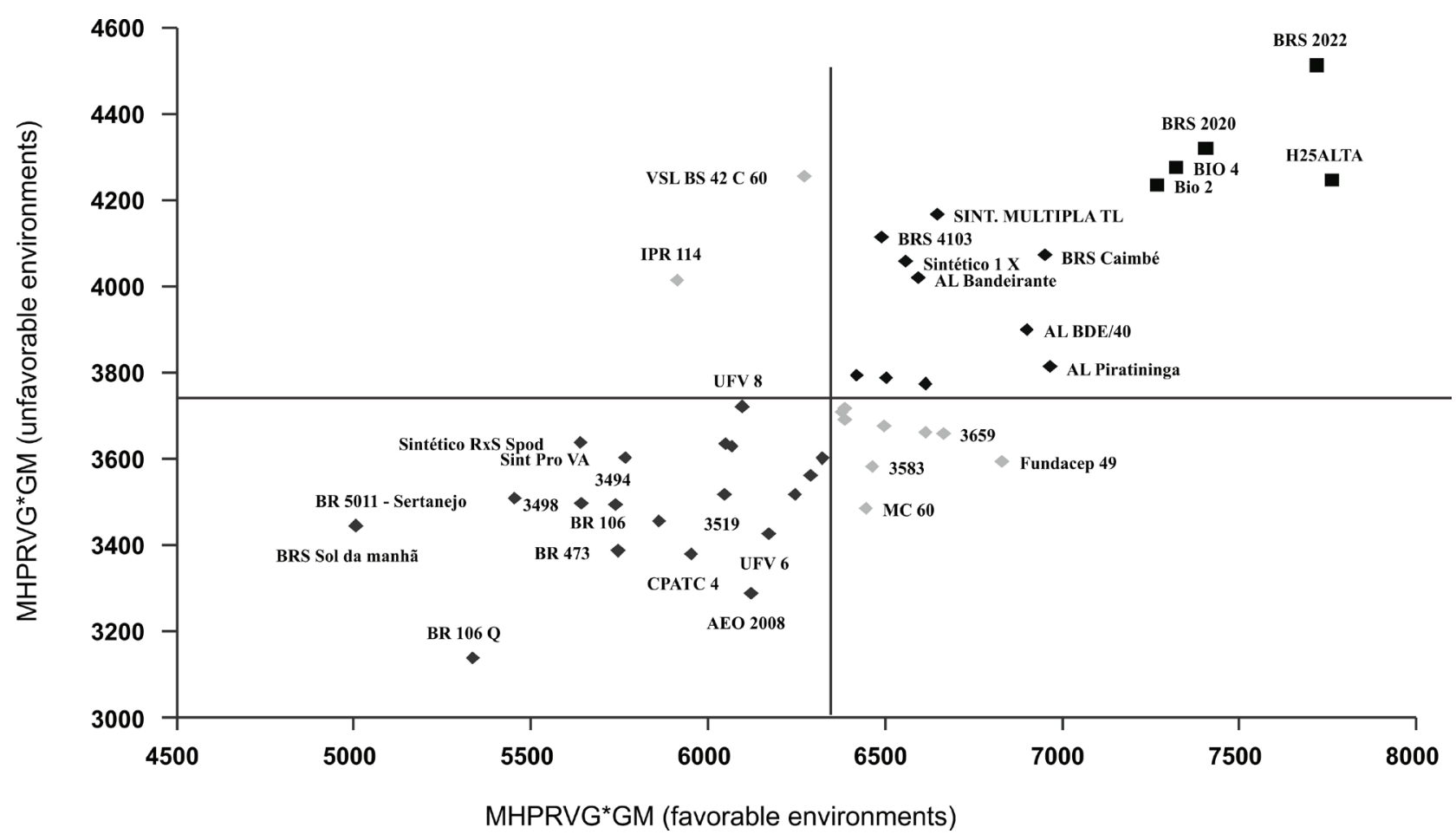

Figure 3. Dispersion diagram of the MHPRVG* GM for grain yield $\left(\mathrm{kg} \mathrm{ha}^{-1}\right)$ of 49 maize cultivars in the favorable and unfavorable macroenvironments.

in the unfavorable environments (Table 4).

In the unfavorable environments the varieties VSL BS 42C60 and Sint. Múltipla TL performed better, yet only the latter variety showed above-average yield in the favorable environments (Figure 3). This seems interesting, since this synthetic had been developed by recombination of elite lines of Embrapa Maize and Sorghum, and had performed exceptionally well in separate stress trials of drought, high aluminum, low nitrogen and low phosphorus. The performance of Sint. Múltipla TL showed that the incorporation of favorable alleles for tolerance to abiotic stresses, contained in the various parental lines, into an open-pollinated cultivar was successful.

A graph visualization of the cultivar performance, using a measure that combines yield potential, adaptability and stability (MHPRVG*GM), led to the identification of productive, stable and widely adapted plant material. Experimental cultivars with this type of behavior are highly promising for commercial purposes, provided that the level of other important agronomic traits, such as resistance to root/stalk lodging and to major diseases, is well-balanced.

The GxE interaction represented $29 \%$ and $17 \%$ of the phenotypic variation in unfavorable and favorable macroenvironments, respectively. Furthermore, the genetic correlation between favorable macroenvironments was 0.60 , and 0.25 for unfavorable macroenvironments, so that in the latter environment group, the interaction was more significant and its complex part higher. These results demonstrate the importance of conducting experiments in specific environments for selection of superior cultivars for certain stress conditions.

It was possible to conclude that the double-cross and intervarietal hybrids performed better than the open-pollinated varieties with regard to the parameters grain yield, adaptability and stability parameters. Among the open-pollinated varieties evaluated, BRS Caimbé, AL BDE/40 and Sint. Múltipla TL were the best for grain yield, adaptability and stability. The MHPRVG method proved suitable for the identification of maize cultivars with high yield potential, wide adaptability and yield stability.

\section{ACKNOWLEDGEMENTS}

The authors are indebted to Embrapa Maize and Sorghum and to the different public and private partner institutions that collaborated in the variety assessments, as well as to the National Council for Scientific and Technological Development (CNPq) for a PhD scholarship. 
FF Mendes et al.

\section{Adaptabilidade e estabilidade de cultivares de milho pelo método de modelos mistos}

Resumo - O objetivo deste trabalho foi avaliar, simultaneamente, o desempenho produtivo, a adaptabilidade e a estabilidade de cultivares de milho, em ensaios desbalanceados, utilizando-se o método da Média Harmônica da Performance Relativa de Valores Genotipicos (MHPRVG). A produtividade de grãos de 45 cultivares, compreendendo hibridos e variedades, foi avaliada em 49 ambientes, em dois anos agricolas. Na safra de 2007/2008 foram avaliados 36 cultivares e na safra seguinte, 25 cultivares, sendo 16 cultivares comuns às duas safras. Foram realizadas análises estatísticas no contexto de modelos mistos considerando genótipos como aleatórios e repetições dentro de ambientes como fatores fixos. Houve alta precisão experimental nas análises conjuntas, com estimativas de acurácia superiores a $92 \%$. Apesar da existência de interação genótipos x ambientes, foram identificados híbridos e variedades com elevada adaptabilidade e estabilidade. Os resultados demonstram que o método MHPRVG mostra-se adequado para utilização em programas de melhoramento de milho.

Palavras-chave: BLUP, modelos mistos, Zea mays.

\section{REFERENCES}

Annicchiarico P (1992) Cultivar adaptation and recommendation from alfalfa trials in northern Italy. Journal of Genetics and Plant Breeding 46: $269-278$.

Bastos IT, Barbosa MHP, Resende MDV, Peternelli LA, Silveira LCI, Donda LR, Fortunato AA, Costa PMA and Figueiredo ICR (2007) Avaliação da interação genótipos x ambientes em cana- de-açúcar via modelos mistos. Pesquisa Agropecuária Tropical 37: 195-203.

Carbonell SAM, Chiorato AF, Resende MDV, Dias LAS, Beraldo ALA and Perina EF (2007) Estabilidade de cultivares e linhagens de feijoeiro em diferentes ambientes no estado de São Paulo. Bragantia 66: 193-201.

Cruz CD, Regazzi AJ and Carneiro PCS (2004) Modelos biométricos aplicados ao melhoramento genético. Editora UFV, Viçosa, 480p.

Fritsche-Neto R, Gonçalves MC, Vencovsky R and Souza Jr CL (2010) Prediction of genotypic values of maize hybrids in unbalanced experiments. Crop Breeding and Applied Biotechnology 10: 32-39.

Henderson CR (1975) Best linear unbiased estimation and prediction under a selection model. Biometrics 31: 423-447.

Lin CS and Binns MR (1988) A superiority measure of cultivar performance for cultivar x location data. Canadian Journal of Plant Science 68: 193-198.
Mi X, Wegenast T, Utz HF, Dhillon BS and Melchinger AE (2011) Best linear unbiased prediction and optimum allocation of test resources in maize breeding with doubled haploids. Theoretical and Applied Genetics 123:1-10

Pinto Jr JE, Sturion JA, Resende MDV and Ronzelli Jr PR (2006) Avaliação simultânea de produtividade, adaptabilidade e estabilidade genotípica de Eucalyptus grandis em distintos ambientes do Estado de São Paulo. Boletim de Pesquisa Florestal 53: 79-108.

Piepho HP, Möhring J, Melchinger AE and Büchse A (2008) BLUP for phenotypic selection in plant breeding and variety testing. Euphytica 161: $209-228$.

Resende MDV (2007a) Matemática e estatística na análise de experimentos e no melhoramento genético. Embrapa Florestas, Colombo, 362p.

Resende MDV (2007b) Software Selegen - REML/BLUP: sistema estatístico e seleção genética computadorizada via modelos lineares mistos. Embrapa Florestas, Colombo, 350p.

Souza Jr CL (2011) Cultivar development of allogamous crops. Crop Breeding and Applied Biotechnology S1: 8-15.

Verardi CK, Resende MDZV, Costa RB and Gonçalves PS (2009) Adaptabilidade e estabilidade da produção de borracha e seleção em progênies de seringueira. Pesquisa Agropecuária Brasileira 44: 1277-1282. 